\title{
A Review of Whale-Watching and Whaling with Applications for the Caribbean
}

\author{
ERICH HOYT \\ Whale and Dolphin Conservation Society \\ North Berwick, Scotland, United Kingdom
}

\section{GLEN T. HVENEGAARD}

\author{
Department of Geography \\ Augustana University College \\ Camrose, Alberta, Canada
}

\begin{abstract}
Whale-watching is a significant and growing tourism industry worldwide. Whaling has a long history and, although largely curtailed today, still occurs in a few countries around the world and in the Caribbean. Whaling has been labeled an incompatible activity with whale-watching because, in some cases, it reduces the number of whales available for use and changes whale behavior. Moreover, in some situations, whale-watching generates greater revenue than whaling, and whaling may detrimentally affect the larger tourism industry because of negative attitudes toward whaling by whale-watchers, other tourists, and host communities. This article examines the potential impacts of whaling on the whale-watching and tourism industries, and places these impacts in the Caribbean context. In doing so, the article outlines the history and current status of whale-watching in the Caribbean, outlines other potential constraints, and highlights the need for research about the impacts and roles of these industries. In the highly competitive global tourism industry, maintaining and nurturing a country's tourism image is critically important.
\end{abstract}

Keywords Caribbean, impacts, tourism, whale-watching, whaling

\section{Introduction}

Whale-watching is an increasingly important economic and recreational activity. In 1998, whale-watching occurred in 492 communities in 87 countries (Hoyt, 2001). More than 9 million tourists participated in whale-watching excursions, which resulted in an estimated \$299.5 million (USD used throughout) in direct expenditures and \$1,049 million in total expenditures. ${ }^{1}$ Since 1991 , global whale-watching numbers increased by $12.1 \%$ per year, while total expenditures (not adjusted for inflation) increased by $18.6 \%$ per year (Hoyt, 2001).

Received 25 May 2001; accepted 18 April 2002.

Address correspondence to Glen T. Hvenegaard, Associate Professor, Department of Geography, Augustana University College, 4901-46 Avenue, Camrose, Alberta T4V 2R3, Canada. Email: hveng@augustana.ca 
In recent workshops and publications, whale scientists identified a number of "incompatible activities" to whale-watching, one of which was whaling (IFAW, 1997; Orams, 2001). There are several factors, from a recreational and tourism perspective, which may contribute to this incompatibility, including reductions in the number of whales available for watching, disturbance to those animals, differing revenues resulting from the two activities, and negative attitudes of whale watchers, other tourists, and host communities.

Such issues are especially relevant in the Caribbean, a region with a large tourism industry, a small but growing whale-watching industry, and a very small whaling industry. In most regions, including the Caribbean, whale-watching attracts foreign tourists and is an important source of foreign currency. In the Caribbean and West Indies, more than 39,000 whale watchers produced about $\$ 10$ million in total expenditures in 1998 (Hoyt, 1999). Although whale-watching is small compared to the entire tourism industry, with over 25 million visitors and expenditures of $\$ 13.5$ billion, whale-watching grew by 20.2\% per year from 1994 to 1998 (Hoyt, 1999). Whaling still occurs in a few eastern Caribbean countries (World Council of Whalers, 2000).

Because whale-watching and whaling have rarely occurred in the same country at the same time (except for Norway and Japan) and studies that directly compare their impacts are lacking, it is difficult to determine cause and effect relationships within and between these industries. However, indicator data from natural and social science research (e.g., whale disturbances, expenditures, and attitudes) suggest some potential impacts. The purpose of this article is to examine some of the impacts that whaling could have on the whale-watching and tourism industry, and place these in the Caribbean context. There are significant cultural differences regarding attitudes to whaling and whale-watching (Hamazaki \& Tanno, 2001), and these are acknowledged in the context of tourists' perceptions.

In this article, whale-watching means watching cetaceans (whales, dolphins, and porpoises) in the wild, either from aircraft, boats, or from land, and can include swimming with cetaceans (IFAW, Tethys Research Institute, \& Europe Conservation, 1996). There are at least three forms of whale-watching. First, in commercial whale-watching, the most common form, tourists pay whale watch operators for a guided opportunity to see cetaceans. The fee usually covers the costs of travel from a predetermined departure point and sometimes covers the costs of a naturalist, hydrophones (to listen to cetaceans), snack food, or other travel conveniences. Second, opportunistic whale-watching is noncommercial in nature, conducted by amateurs on an ad hoc basis. Third, research whale-watching, the conduct of nonlethal research on live cetaceans, is carried out by independent researchers, sometimes alongside or in conjunction with commercial whale watch operations. This article focuses primarily on commercial whale-watching.

Cetacean hunting includes the hunting of small cetaceans (toothed whales including beaked whales, pilot whales, and various dolphins) and large cetaceans (sperm whales and baleen whales such as humpback and minke whales). The term "whaling" is widely used, but usually refers to the hunting of the larger whales. This article will use "cetacean hunting" when discussing most Caribbean-specific issues, since Caribbean hunters mostly target small cetaceans, and will use "whaling" when discussing these issues in a global sense.

\section{The Compatibility of Whale-Watching and Whaling}

Whaling has been described as "incompatible" with whale-watching (IFAW, 1997; Orams, 2001) for several reasons. From a supply perspective, whaling directly removes live animals from the local population and disturbs the whales or alters their regular activities 
(IFAW, 1997). Thus, whaling could decrease the number of whales available for whalewatching or encourage avoidance responses to boats. From an economic perspective, in some instances, using whales for whale-watching could generate greater revenue than using the whales for whaling. Finally, from a tourism and recreational perspective, there may be differences in attitudes of whale watchers, other tourists, and host communities toward whaling and whale-watching, which could have an impact on the tourism industry. According to one report, "whale watchers may be philosophically opposed to whaling and, given the choice, may be unlikely to favor whale-watching operations in countries that hunt whales (or those that support whaling) even if the whaling targets a different species than the whale-watching" (IFAW, 1997, p. 27). While it is not the intention of this article to examine the ethical nature of whaling and whale-watching, it is important to examine how those ethical choices affect the attitudes and activities of tourist groups who might go whale-watching.

\section{Does Cetacean Hunting Result in Fewer Numbers of Whales for Whale-Watching?}

A lack of baseline knowledge on population structure and habitat use of most cetaceans makes it difficult to determine the exact impacts of whaling on whale-watching. However, reductions in whale populations by whaling certainly reduce the potential number of whales for whale-watching.

A few examples from countries where whaling currently occurs will help illustrate the range of potential impacts on whale-watching. With whale-watching in Norway based largely on sperm and killer whales, the whaling of minke whales in Norway does not result in fewer whales for whale-watching. In contrast, minke whales in Iceland are the mainstay of the whale-watching industry around Húsavik, and individual whales are now known to operators, local residents, and visiting tourists. If minke whaling in Iceland were to resume, it could reduce the numbers of whales, possibly even removing some of the locally known whales. In Japan, the hunting of minke, pilot, and Baird's beaked whales, as well as Pacific white-sided dolphins and Dall's porpoises, could reduce the number of cetaceans available for local tourism from several whale watch ports located around Hokkaido Island, especially at Volcano Bay and on Nemuro Strait.

Off far-eastern Russia, for many decades, 140-160 gray whales per year have been taken in the aboriginal harvest by Siberian Eskimos and a few by Alaskan Natives (Jones \& Swartz, 2002). Commercial whaling in the late 19th century came close to driving this population extinct, but the current aboriginal kills have not stopped the eastern North Pacific population from returning to presumed pre-exploitation levels. However, in the North Atlantic, whaling is thought to be responsible for, or to have contributed to, the extinction of the western North Atlantic population (in about 1730) and the eastern North Atlantic population (500 AD, but one record in the early 1600s) as well as the near-extinction of western North Pacific grays (reduced to fewer than 100 animals) (Weller et al., 1999; Jones \& Swartz, 2002). Gray whales are particularly susceptible to whaling and other human influences because of their near-shore feeding and breeding habits. It was only because whaling in the eastern North Pacific was curtailed in time throughout most of their range that the whales were able to return from low numbers to become the mainstay of the west coast American and Mexican whale watch industries.

Fewer whales due to cetacean hunting can also mean fewer cetaceans for other uses besides whale-watching. The following list includes both complementary and competing uses: photo-identification and other research (including use of cetaceans as biological indicators); removal (capture for aquaria, research, military purposes); commercial deep 
sea fishing (dolphins helping to find commercial fish species); traditional cooperative fishing (e.g., dolphins helping to drive and catch fish); icons (art, souvenirs, literary, political, conservation, advertising/marketing uses); cultural (e.g., social and religious purposes); filming and photography (including collecting sounds for commercial recordings); medical uses; and dolphin therapy (IFAW, 1999).

Overall, the impact of cetacean hunting on the number of whales for whale-watching depends on the species and age/sex groups targeted by cetacean hunters, the proportion of animals removed relative to the target population, and the geographic and temporal overlap of hunted versus watched whales. Each situation will have a different threshold at which the impacts become significant.

\section{Does Cetacean Hunting Disturb Whales or Dolphins in a Whale-Watched Population?}

Incomplete information on cetacean biology and habitat use makes it difficult to determine impacts with certainty. There is some evidence that cetaceans are more wary of boats following exposure to whalers, dolphin hunters, fishing nets, or other fishing tackle lethal to cetaceans. The responses almost certainly vary by species, population, and local situation. However, just as Watkins (1986) found that minke, fin, right, and humpback whales in the Cape Cod area varied in their reactions to whale-watching boats, shortand long-term reactions of cetaceans to hunting boats could be expected to vary. Certain populations of whales that periodically travel or feed alone, in pairs, or widely spaced apart, might have little opportunity to develop a learned response to hunting, while the more social odontocetes and certain baleen whales could readily develop such responses if only part of the group was removed.

$\mathrm{Au}$ and Perryman (1982), for example, found that dolphin schools in the eastern tropical Pacific would leap away rapidly from tuna vessels only in areas where they were intensively "set-upon." Similarly, bowhead whales on the Alaskan North Slope are extremely wary of all motorboats in spring and autumn during the time when they are hunted (B. Würsig, personal communication, 1999). From the air, they can be seen skulking around an ice floe, always diametrically opposed to the boat trying to approach them. However, the effect may only be short term as bowheads are not wary in midsummer, outside the hunting season, nor are other bowheads further to the east in Canadian waters wary at all. Similarly, the limited annual aboriginal hunting of eastern North Pacific gray whales in part of their feeding grounds off Siberia does not appear to adversely affect migrating or wintering grays that are approached by whale watchers in large numbers from the west coast of Canada, the United States, and Mexico. In west Greenland waters (e.g., the Disko Bay area), fin whales have been found to be much more difficult to approach than elsewhere, even by nonwhaling boats, in areas where they have been hunted recently, presumably because of a learned avoidance response (P. Clapham, personal communication, 1999).

Some cultures may question whether it is appropriate to hunt animals from a population of cetaceans that is regularly whale watched. Animals that are frequently exposed to whale watchers often become used to boats, and some species approach boats more often following prolonged exposure (Watkins, 1986). Although this does not result in taming the animal, it might allow hunters to approach and kill such animals more easily than those which have only been exposed to hunters or not exposed to humans in any concerted way.

With the limited evidence available, cetacean hunting may cause at least short-term reactions in hunted cetacean populations. More research on the long-term impacts is needed. 


\section{Does Whale-Watching Generate More Revenue than Cetacean Hunting?}

It is difficult to make direct comparisons of the economic benefits of whaling and whalewatching. The peaks of these industries occurred at different times and only a few nations still hunt whales. Economic estimates for whale-watching usually indicate total expenditures, as defined above, while whaling estimates focus on sales revenue to the whalers or whaling companies. Both whale-watching and whaling need to be compared on the basis of consumer surplus, rate of return, and net benefits in a comprehensive economic welfare and economic impact assessment (Moyle \& Evans, 2001; IFAW, 1999; Hoyt, 2001). In addition, many of these benefits (e.g., use, option, existence, and bequest values) and costs may be difficult to quantify or even distinguish (IFAW, 1999; Moyle \& Evans, 2001) and benefits may leak out of a local economy (Hvenegaard, 1997).

Detailed comparisons have yet to be made using methods suggested at the Socioeconomic Workshop on Whale-Watching (IFAW, 1999), which addressed a wide variety of economic, social, cultural, and political aspects of whale-watching as well as other uses of cetaceans, including whaling. Nevertheless, a few direct comparisons have been made on global, national, or local scales. These expenditure or revenue comparisons should be treated cautiously, based on the concerns raised above. On a global scale, Kraus (1989) attempted to compare the revenue from whaling with total expenditures by whale watchers. In 1988, whaling brought in an estimated $\$ 154$ million in total revenues to the whalers, while whale-watching produced $\$ 56$ million in total expenditures. Expenditures by whale watchers have since grown to \$1,049 million in 1998 (Hoyt, 2001). No similar current estimates are available for whaling.

A national perspective is provided from Iceland, where total expenditures by whale watchers were an estimated $\$ 10$ million in 1998. This compares to the annual revenues from whaling during its peak (1980-1985) of \$21 million and to the annual revenues of scientific whaling during 1986-1989 of \$4.5-6 million (A. Bjorgvinsson, personal communication, 1999).

Finally, two comparisons at the local scale are available. First, Hoyt (1993) looked at the value of approximately 16 resident Bryde's whales at Ogata, Japan, for whaling and whale-watching. If whaled, the meat would produce $\$ 4.3$ million in revenues, which would be worth more than whale-watching in a single year, but if considered over a longer period (e.g., 15 years), if tourist numbers stayed the same, whale watchers would spend $\$ 41.4$ million.

Second, comparisons are available for Norway's Vesteralen and Lofoten Islands, where 7-9\% of all visitors to the islands now go whale-watching (Gößing, 1997). In 1994, whale watchers spent $\$ 3.3$ million in Andenes county, compared to the revenue of $\$ 2.1$ million brought in by whaling during the same year (WDCS, 1998). The whaling industry employed an estimated 250-300 people during a two-month season, while the whale watch industry employed about 52 people during the two- to four-month whale watch season, with an additional nine people working year round (Gößling, 1997).

Comparisons can also be made with similar studies on land-based species that compare the value of watching to hunting. For instance, an adult male lion in Amboseli National Park, Kenya, will draw \$515,000 in foreign exchange revenue for wildlife watching, compared with $\$ 8,500$ for sport hunting or $\$ 1,324$ for a commercial skin (Thresher, 1981). An elephant herd for viewing in Amboseli is worth $\$ 610,000$ per year; hunting would result in less than $10 \%$ of this value (Western \& Henry, 1979).

In general, over the short term, whale-watching and whaling appear close in terms of visitor expenditures and revenues, but over the long term, the gap widens with whalewatching increasing. Both whale-watching and whaling, however, are dependent on markets: 
tourists and whale meat consumers. Many more factors, costs, and benefits need to be taken into account before definitive comparisons can be made.

\section{Do Whale Watchers Have Differing Attitudes toward Cetacean Hunting and Whale-Watching?}

Given the large and growing interest in, and economic impact from, whale-watching activities around the world, it is useful to examine the attitudes of whale watchers toward whaling. There is strong evidence that whale watchers do not accept whaling. In a survey of whale watchers in California (Tilt, 1987), 75\% agreed that it is morally wrong to kill whales. Duffus (1988) surveyed whale watchers on Vancouver Island, British Columbia, Canada, about their attitudes toward a variety of issues relevant to whales, using a scale of 1 to 5 (where $1=$ strongly disagree and $5=$ strongly agree). For the statement "It is wrong to kill whales," the average response from whale watchers was 4.47. For the statement "Commercial whaling should be stopped," the average response from whale watchers was 4.42 . However, only $25 \%$ of BC whale watchers knew that hunting of whales still occurred in Canada at the time.

In a survey of New England whale watchers, a total of $83 \%$ agreed (strongly agreed $=57 \%$; moderately agreed $=26 \%$ ) that it is morally wrong to kill whales regardless of the reason (Lewis, 1988). As well, $50 \%$ of whale watchers had given money to a whale protection organization, 59\% had signed a petition calling for a halt to the killing of whales, and $92 \%$ would rather pay a higher price for tuna than see the tuna industry continue killing dolphins in their nets (strongly agreed $=72 \%$; moderately agreed $=$ 20\%). Whale watchers in South Australia held similar attitudes supporting whale protection (Reid, 1993, 1996).

The opposition of whale watchers to whaling is stronger than the opposition of land-based wildlife watchers to hunting. Surveys of land-based wildlife watchers in the late 1970s indicated positive to neutral attitudes toward hunting activities. For example, in nationwide surveys of American wildlife watchers, only 29\% disapproved of sport hunting (Keller, 1978). Shaw et al. (1978) found that $45 \%$ disapproved of all hunting. Among nonhunting wildlife enthusiasts visiting southern Arizona, only $12 \%$ agreed that hunting should be banned to help wildlife (Straw \& King, 1980).

However, More (1979) predicted that anti-hunting sentiments would increase. Recent studies show that land-based wildlife watchers are less approving of hunting than in the past. Adams, Leifester, and Herron (1997) found that birders disagreed slightly that hunting is necessary to prevent waterfowl overpopulation and agreed just slightly that hunting should continue as a management tool. Disapproval of hunting increases for females, younger ages, and urban residents (More, 1979).

Given that whale watchers disapprove of whaling, it is expected that whaling would reduce the quality of the whale watchers' experiences. Many factors increase satisfaction for whale watchers; these include encountering whales, close observation of whales, seeing examples of whale behavior, and seeing other marine mammals (Duffus, 1988; Muloin, 1998; Orams, 2000). Such expectations are similar to those of land-based wildlife watchers (e.g., many species of wildlife, large mammals, higher numbers of particular species, and higher numbers of all wildlife; Hammitt, Dulin, \& Wells, 1993).

Thus, whale populations with whaling pressure could reduce satisfactions for whale watchers. Fewer whales, fewer species of whales, or more wary whales would reduce significantly the satisfactions of whale watchers. Opposite trends could increase satisfactions (McCloskey, 1983). Satisfactions help determine the economic value of whalewatching, which, when measured as consumer surplus, is significant. In Massachusetts and Californa, the estimated consumer surplus ranges from \$25 (Hoagland \& Meeks, 
1997 ) to $\$ 33$ (Day, 1987) to $\$ 43-\$ 50$ per person per day (Loomis, Yorizane, \& Larson, 2000).

In addition to the strong opposition to whaling, whale watchers have broad concerns about the whale-watching industry and its potential impact on the whales (Tilt, 1987; Baird, Otis, \& Osborne, 1998; Duffus, 1988). For example, the perception that boats harass killer whales is greater from land-based whale watchers than from boatbased whale watchers. Boats impact detrimentally on the whale-watching experience of land-based whale watchers more frequently than they do for boat-based whale watchers (Baird, Otis, \& Osborne, 1998).

\section{Do Other Tourists Have Differing Attitudes toward Cetacean Hunting and Whale-Watching?}

Attitudes toward whaling vary by country. In a six-country survey, opposition to whaling under any circumstances was highest for residents of Australia (60\%), the United States (57\%), and Germany (54\%), and lower for England (43\%), Japan (25\%), and Norway (22\%) (Freeman \& Kellert, 1992). Hamazaki \& Tanno (2001) found that public approval of whaling was positively correlated with whaling maintenance objectives, approval of scientific management of whaling, and knowledge about whaling, but negatively correlated with whale conservation objectives. Few demographic variables were correlated.

In the United States, a large source of foreign tourists, opposition to whaling is growing (Lavigne, Scheffer, \& Kellert, 1999). A recent survey found that $70 \%$ of Americans are opposed to commercial whaling under any circumstances (Kellert, 1999). It should be mentioned that $80 \%$ also object to interfering with whale behavior for whale-watching. Tourists and the general public are most concerned about commercial whaling; genuine subsistence whaling is more acceptable (Lynge, 1992; Freeman \& Kellert, 1992; Orams, 2001). For example, more than $70 \%$ of the American public endorsed the right of native peoples to hunt abundant marine mammals if this use was for personal food consumption and/or to obtain clothing (Kellert, 1999).

In addition, on-site tourists have also indicated their displeasure toward whaling. In Tonga, $95 \%$ of airplane visitors and $83 \%$ of yacht visitors are opposed or strongly opposed to the commercial hunting of whales (Orams, 2001). If tourists choose not to visit a country because that country hunts whales, this could reduce revenues for all types of tourism, including whale-watching. In Tonga, $78 \%$ of airplane visitors and $62 \%$ of yacht visitors would be less likely to holiday at a location where whales were hunted. Similarly, $73 \%$ of airplane visitors and $65 \%$ of yacht visitors would be less likely to holiday in Tonga if whales were hunted there (Orams, 2001). Orams concluded that it is unlikely that a whale-watching industry could coexist with a lethal use of whales in Tonga.

According to a 1997 survey conducted by the Icelandic Board of Tourism, 54\% of visitors said that the resumption of whaling would have negative effects on their decision to come to Iceland (29\% very negative; $25 \%$ rather negative). The tourism industry in Iceland generates about $\$ 310$ million per year in foreign exchange revenue. The number of tourists would have to drop by only $7 \%$ for the revenue loss to equal the previous income from whaling, about $\$ 21$ million per year in the mid-1980s (A. Finnsson, personal communication, 1998).

Despite the potential for fewer tourists in Tonga and Iceland, if whaling industries return, these countries could still attract unknown numbers of tourists. This may be explained by (1) inconsistent intentions and actions from those who said they would not travel; (2) visitors who want to support whale-watching operations within whaling countries; and/or (3) a replacement of tourists opposed to whaling with tourists unaffected by or supporting whaling in the host country. 
With regard to tourists' attitudes toward whale-watching, even though many tourists do not take part in a whale-watching experience, that option itself is appealing and may enhance the overall tourism experience. For example, in California, hundreds of thousands of people attend some nine annual whale-watching festivals lasting from one day to two weeks which have considerable socioeconomic impact in coastal communities. Only a fraction of the visitors actually go whale-watching but they enjoy participating in the celebration of the gray whale migration (Hoyt, 2001). In addition, 50\% of Hawaii tourists indicated that humpback whales were at least a small factor in their decision to come to Hawaii for $10 \%$ of tourists, humpbacks were one of several important factors, and for $3 \%$ of tourists, humpbacks were a very important factor (Utech, 1999). In Tonga, $43 \%$ of airplane visitors and $37 \%$ of yacht visitors considered whales important or extremely important in choosing to visit Vava'u (Orams, 2001). In sum, the opportunity to watch whales may increase a tourist's motivation to visit a tourist destination, and cetacean hunting may have an opportunity cost in lost tourists and revenues if tourists choose alternate destinations.

\section{Do Host Communities for Whale-Watching Have Differing Attitudes toward Whale-Watching and Cetacean Hunting?}

There have been no surveys of whale watch communities to show any preference toward either whaling or whale-watching, but host communities have indicated that they are satisfied with whale watchers and the whale-watching industry. For example, Dowling (1991) surveyed residents of Shark Bay in Western Australia about dolphin watchers and their activities. Most residents agreed that tourists do not diminish their enjoyment of the area $(66 \%)$ and do not place a burden on the local services $(61 \%)$. As well, $69 \%$ of residents agree that tourism generates more money for the local people than other commercial activities.

Other qualitative studies indicate local support for the whale-watching industry. Darling (1991) describes the positive reaction of communities in Ogasawara, Japan, about the change toward whale-watching from whaling, as the whale-watching industry began soon after whaling ceased. Hoyt $(1996 \mathrm{a}, 1996 \mathrm{~b})$ also noted positive socioeconomic changes in Ogata, Zamami, and other Japanese whale watch communities and compared these changes to those in other whale watch communities such as Tofino, BC, Canada; Provincetown, MA, USA; and Kaikoura, New Zealand.

Some communities have been transformed by whale-watching. For example, Kaikoura, New Zealand, was an economically depressed town for some years before whale watchers started coming in 1987 to see sperm whales in the deep waters just offshore (Hoyt, 1994a). By 1991, 44 businesses were added to the community, mainly because of the influence of whale-watching. By 1994, more than 25 times the number of visitors $(100,000)$ came to Kaikoura than in 1986, the year before whale-watching began.

Because of the pioneer success of Kaikoura, other communities in New Zealand have applied for permits to start whale and dolphin watching industries. In 1995, 8\% of visitors to New Zealand went on whale watches and $14 \%$ on dolphin watches (New Zealand Tourism Board, 1996). As of March 1999, there were 103 marine mammal watching permits or outstanding applications for permits held by tour operators all over New Zealand (Suistead, personal communication). Besides Kaikoura, a total of 74 permits have been issued at 26 sites from Maunganui to Stewart Island (Constantine, 1999).

An example of changing attitudes toward tourism for a land-based wildlife watching site comes from Rwanda. Weber (1987) found that community support for wildlife viewing tourism increased substantially after implementing a gorilla watching program. Local residents perceived that national, regional, and personal benefits increased after 
implementing gorilla viewing tours. McCool (1996) argues that rural communities that are undergoing rapid social and economic change have a significant opportunity to offset economic downturns by turning to the wildlife viewing industry. This is because wildlife viewers often contribute economically during shoulder or off-seasons (Hvenegaard, Butler, \& Krystofiak, 1989) and consistently spend more in local areas than other visitor groups (McCool, 1996). A prime example of whale-watching contributing economically to shoulder or off-season tourism is the gray whale migration which occurs through the winter and spring from California to Alaska (Hoyt, 2001).

In addition, tour operators, though not representative of communities, have opinions about whaling. For example, among tour operators in Tonga, 100\% were opposed to commercial whaling and 66\% were opposed to indigenous whaling (Orams, 1999). All operators strongly agreed that a return to whaling practices of any type in Tonga would be detrimental to their businesses. Of 13 whale watch operators in Iceland, 11 were opposed to the resumption of whaling in that country (Bjorgvinsson, 1997).

Whale watch operators and whalers in Andenes, Norway, seem to have developed more understanding and tolerance of each others' positions (Goddard, 2000). Ris (1993) suggests that residents of Norway do not necessarily have to choose between whaling and whale-watching because of their heritage of respect for nature and "harvesting" living natural resources. Ris suggests that the dichotomous choice between whaling and nonconsumptive uses of whales is forced on Norwegians by foreign entrepreneurs and Anglo-Americans.

There have been no studies of whale-watching communities and cetacean hunting communities which would allow a direct comparison of residents' attitudes and values. In the future, this may be a useful line of inquiry, but the same methodology must be used in all communities and time periods and all the values must be considered in economic welfare as well as economic impact assessments.

\section{Whale-Watching and Cetacean Hunting in the Caribbean}

\section{Background}

More than a third of all cetacean species-some 30 species-spend part or all of their year in the Greater Caribbean (the West Indies, including the Bahamas and the Turks and Caicos Islands; Jefferson, Leatherwood, \& Webber, 1993). Several baleen whales, notably humpback whales, are seasonally present on their winter grounds during a period that broadly corresponds with winter tourism peaks in the Caribbean. Odontocetes, such as sperm whales and various dolphins, can be watched year-round, offering additional reasons for tourist visits in the low or off-season. The presence of these cetaceans offers considerable whale-watching opportunities throughout the Caribbean.

Commercial whale-watching in the greater Caribbean began in the early to mid1980s with the development of dolphin watching and swimming tours in the Bahamas and humpback whale-watching off the Dominican Republic (Hoyt, 1994b). In 1988, commercial whale-watching started in the eastern Caribbean with tours to see sperm whales and various dolphins off Dominica. Whale-watching in the above three countries has grown steadily and spread to other nations and nearby islands. By the mid-1990s, whale-watching attracted visitors to the Turks and Caicos Islands, the U.S. and British Virgin Islands, Martinique, and St. Vincent and the Grenadines. Since the late 1990s, whale watch tours have also started in Puerto Rico, St. Kitts-Nevis, Grenada, St. Lucia, St. Barthelemy, and Guadeloupe. In these and other Caribbean countries and island territories, there is potential to expand whale-watching activities (Hoyt, 2001).

The number of commercial whale watchers and their expenditures has also grown 
rapidly. In 1991, 1,914 people went whale-watching in the greater Caribbean, spending about $\$ 1.7$ million in total expenditures, but by $1994,18,700$ whale watchers spent $\$ 6.6$ million. In 1998, more than 39,000 whale watchers ${ }^{2}$ spent about $\$ 10$ million (Hoyt, 1999). Based on the number of whale watchers, the average annual increase between 1994 and 1998 was $20.2 \%$, which was higher than the global rate of $13.6 \%$. Between 1991 and 1994, whale watcher numbers in the region grew much faster, at $113.8 \%$ per year, also higher than the global rate of $10.3 \%$ (Hoyt, 1994b, 1995, 2001). Given these rapid rates of increase, there is significant potential for growth in the commercial whalewatching industry. In 1994, 10 countries or island territories (out of 23) participated in commercial whale-watching; by 1999 , this had grown to 14 countries and territories. The countries with the highest total whale watcher expenditures include the Dominican Republic (\$5.2 million), Bahamas (\$2.97 million), and Dominica $(\$ 970,000)$.

There are no studies of opportunistic whale-watching in the Caribbean, but contributions (e.g., sighting and stranding reports) to the Eastern Caribbean Cetacean Network indicate considerable interest among fishermen, yachters, and coastal residents (Hoyt, 1999). In addition, some of the 10.6 million cruise ship passengers in 1997 (Hoyt, 1999) watch whales opportunistically. Marketing efforts make some use of advertisements that highlight the potential to see whales on cruises. Boat passengers have a number of motives for joining a tour or cruise, one of which could be whale-watching. For example, $75 \%$ of the Maui, Hawaii, dinner cruise, and snorkeling tour passengers knew that humpback whales would be present in Hawaiian waters during their visit (Utech, 1999). In addition, $57 \%$ of snorkeling passengers and $21 \%$ of dinner cruise passengers indicated that whale-watching was one of the reasons they chose to go on their trip. In the Caribbean, if cruise ship tourists are not included, this form of whale-watching likely involves fewer participants than commercial whale-watching.

Similarly, there are no studies on the extent of research whale-watching. Whale research has developed in tandem with commercial whale-watching in many parts of the world (Papastavrou, 1996), including the Caribbean. Since the early 1980s, spotted and bottlenose dolphin-watching trips have helped pay for research in the Bahamas (both commercial trips and scientific surveys through Earthwatch). This research, in turn, provides benefits to the commercial whale watch operators through, for example, the provision of sighting records and interpretation of cetacean behaviors. Intensive humpback whale photographic identification work has taken place since the 1980s, before and during the high-profile Years of the North Atlantic Humpback (YONAH) project, sometimes on commercial whale watch trips, mainly in the waters of the Dominican Republic, but extending to the waters of the Turks and Caicos Islands, U.S. and British Virgin Islands, and Puerto Rico (Smith et al., 1999). In addition, there have been large whale surveys and Blainville's beaked whale photo-identification studies in the Bahamas (Hoyt, 1999) and some other work on sperm whales in the region (e.g., Gordon et al., 1998). Outside of the Bahamas, there has been comparatively little work on most small cetaceans in the Caribbean.

The various local and foreign researchers conducting studies on cetaceans in the Caribbean, provide many important economic, scientific, conservation, management, and educational benefits. Economically, researchers are likely to stay for an extended period of time and some researchers bring in foreign currency. Scientifically, they gather valuable behavioral, distribution, and population data about whales, all of which helps enhance and develop the commercial whale-watching industry. Researchers can improve conservation and management by, for example, locating ecologically significant whale populations, identifying potential reserve areas, and studying the impacts of whale-watching on the whales. Finally, researchers provide valuable information that can be used to educate whale watchers, other tourists, and residents about whales. 
In terms of expenditures (not in terms of the number of whale watchers), whalewatching has not grown as quickly in the Caribbean as in other areas of the world (Hoyt, 2001). There are several possible factors behind this slower growth:

- First, there is a lack of investment in whale-watching infrastructure, such as boats specifically designed for whale-watching.

- Second, marketing has been insufficient to develop a higher profile for whale-watching to attract more tourists to the whale-watching opportunities. Instead, the market for tourism to certain islands is dominated by cruise ships or inflexible package holidays, which rarely include whale watches. As well, the lack of trained naturalists on whale watches inhibits direct and word-of-mouth marketing.

- Third, there has been a lack of effective management and monitoring of whale-watching, in terms of regulations and guidelines from local governments and approval schemes from industry associations. Such initiatives by government and industry associations are needed to address perceived or possible impacts on whales, as well as education and safety issues, all of which are of prime concern to tourists, tour operators, and conservationists.

- Fourth, there is incomplete research on cetacean populations in the area, which limits the potential for whale watch operations.

- Finally, the persistence of a few cetacean hunting industries in the region and support of cetacean hunting may be affecting all three forms of whale-watching and the larger tourism industry. Historically, cetacean hunting has occurred throughout the Caribbean (Caldwell \& Caldwell, 1971; Reeves, 1988; Vidal \& Van Waerebeek, 1994; Romero \& Hayford, 2000), with impacts continuing to the present day which may affect whale abundance and distribution.

Prior to the late 1800s, the only direct use of whales occurred with strandings, such as with pilot whales. Commercial cetacean hunting began in the late 1800s, as whalers came from the United States to hunt primarily humpback and short-finned pilot whales (Ellis, 1991). With the technology gained from foreign whalers, local whaling began at the same time. Since the 1920s, as desired whales became scarce, only local residents have hunted whales in the Caribbean (Ellis, 1991). For a period, whaling was an important economic activity, but was negatively affected by a number of factors, including rising fuel costs, dwindling markets, and declining whale stocks.

In recent years, limited and small-scale cetacean hunting, with a focus on shortfinned pilot whales, pygmy killer whales, humpback whales, killer whales, beaked whales, and a variety of dolphin species, has occurred in a few eastern Caribbean countries, including St. Vincent and the Grenadines, St. Lucia, Dominica, and Grenada (Caldwell \& Caldwell, 1971; Vidal \& Van Waerebeek, 1994; Reeves, 1988; Ward \& Moscrop, 1999; World Council of Whalers, 2000). Hunting of two humpback whales per year in St. Vincent and the Grenadines is permitted under an "aboriginal whaling" clause of the International Whaling Commission (IWC) (Quimby, 2000). Directed hunts in Barrouallie, St. Vincent, and occasional hunts off Dominica and St. Lucia (Reeves, 1988) usually focus on pilot whales and other smaller odontocetes. Six Caribbean island nations are members of the IWC, although it does not regulate these small cetacean kills.

\section{Potential Impacts of Cetacean Hunting on Whale-Watching in the Caribbean}

This section will apply the specific points made in the previous section on "The Compatibility of Whale-Watching and Whaling" to the Caribbean. The potential impacts on commercial whale-watching raised here are likely to be similar to those on opportunistic and research whale-watching.

Does cetacean hunting result in fewer whales for whale-watching in the Caribbean? Whale-watching largely depends on the reliable presence of cetaceans in reasonably 
protected, near-shore waters (Hoyt, 2001). These are also the prime conditions for local cetacean hunting which was popular throughout the Caribbean and persists today in the eastern Caribbean. It is known that many toothed and baleen whale species have site fidelity, returning repeatedly to favored feeding, nursing, and breeding areas (Taylor, 2002). However, without baseline cetacean habitat studies, it is difficult to know which cetacean populations may have been affected, even lost, due to local cetacean hunting. It is possible that some toothed whales were driven out of near-shore habitats, rather than eliminated.

However, records do exist of intensive episodes of larger scale whaling in the Caribbean, particularly of humpback whales. Humpback whales are the most popular and accessible whale for whale-watching worldwide and overall in the Caribbean (Hoyt, 2002). The intensive historic whaling of humpback whales, throughout the Caribbean and on migration routes and northern feeding grounds in the North Atlantic, is likely the most significant factor affecting the development of whale-watching in the Caribbean.

To some extent, whale-watching started up and became popular in the Caribbean as humpbacks began to return in some numbers to the near-shore waters of Samaná Bay, in the Dominican Republic in the 1980s. Significantly, humpback whale-watching did not begin in the Turks and Caicos Islands and Puerto Rico until humpback whales began to show up close to shore in the late 1990s (Hoyt, 1999, 2001). In the British and U.S. Virgin Islands, the low level of humpback whale sightings there was not sufficient to sustain whale watch tours despite keen interest from both locals and visitors (Hoyt, 1999).

In the eastern Caribbean, whale-watching has developed more slowly, based around sperm whales and various dolphins. From St. Vincent and the Grenadines, the current hunting of humpback whales at a relatively low annual rate does not seem to affect the success of humpback whale-watching in the Dominican Republic or the Turks and Caicos Islands. However, the usual targeting of calves and mothers, critical for restoring depleted humpback populations, may reduce the potential for a future whale watch industry based on humpbacks not only in St. Vincent and the Grenadines but throughout the eastern Caribbean.

With regard to the second aspect of compatability, no studies examine the potential disturbance of whales by whale hunting in the Caribbean. However, research elsewhere indicates at least some avoidance responses to boats caused by hunting activities. In 1996, a workshop in Dominica on the "Special Aspects of Watching Sperm Whales" brought together world experts with local whale watchers to stimulate research into the effects of whale-watching on sperm whales and to recommend precautionary management (IFAW, 1997).

Third, direct comparisons between the expenditures of whale watchers and revenue from whaling are difficult to make for the reasons described earlier. Moreover, estimates of whaling revenues are not available for the Caribbean. However, whale watchers in the Caribbean spent more than \$10 million in 1998 (Hoyt, 1999).

The fourth and fifth compatibility questions (do whale watchers and other tourists have differing attitudes toward hunting and whale-watching?) are examined together since there are few studies of whale watchers in the Caribbean, and none that examine their attitudes toward cetacean hunting or whale-watching. However, since most Caribbean tourists (and whale watchers) originate from the United States and western Europe (Hoyt, 1999, 2001), their opposition toward cetacean hunting, and potential effects on travel decisions, should be considered.

In 1998, 39,000-89,000 whale watchers in the Caribbean spent \$10-\$10.5 million in total expenditures. In comparison, in 1997, the Greater Caribbean region received 15.1 million visitors by air and 10.6 million visitors by cruise ship, with total expendi- 
tures of $\$ 13.5$ billion. Although the size and economic impact of the commercial whalewatching industry is comparatively small, it contributes to a positive image, in terms of attractions and recreational opportunities, which benefits the entire tourism industry (Hoyt, 1999, 2001). As other studies have shown, the presence of cetaceans may enhance the attraction of a destination (Utech, 1999).

Conversely, cetacean hunting may detract from tourists' interest in visiting a destination (Orams, 2001). For example, in 1999, a humpback whale mother and calf were killed off Mustique Island (part of the Grenadines), resulting in considerable criticism from tourists (Hoyt, 1999; WDCS, 1999). Taken one step further, some organizations, such as the International Wildlife Coalition, have even promoted tourism boycotts of nations that continue whale hunting (e.g., St. Vincent and the Grenadines; International Wildlife Coalition, 2000). Although not widely known by the public, the political prowhaling stance by some Caribbean countries (Fisher, 2001) could influence whale watchers' and tourists' attitudes about visiting a particular country.

Finally, do host communities have differing attitudes toward cetacean hunting and whale-watching? Local community festivals demonstrate support for whale-watching in the Caribbean. In Puerto Rico, during the season when humpback whales are present, weekend festivities at a land-based whale-watching site near Rincón attract thousands of visitors (Hoyt, 1999). A Festival de las Ballenas was held in 1998 in the Dominican Republic at Samaná Bay, organized through local volunteer help. Furthermore, whale watch workshops, organized with broad support from local communities, whale watch operators, researchers, conservation, and governments, have been held in the Turks and Caicos Islands and Dominica. There are no known community festivals that celebrate whaling, although a museum commemorating the whaling industry has been established at Point Hilary, on the island of Bequia, in St. Vincent and the Grenadines (Ellis, 1991).

\section{Research on Whale-Watching in the Caribbean}

There is concern about the impacts of cetacean hunting on whale-watching and tourism industries. More research effort is needed to evaluate these impacts in an appropriate and consistent manner. There is also concern about the long-term impacts of whalewatching, in all its forms, on whales and dolphins (Tilt, 1987; IFAW et al., 1996; Baird, Otis, \& Osborne, 1998), which also requires additional research. A key response to these research needs, recommended in the 1995 Workshop on the Scientific Aspects of Managing Whale-Watching (IFAW et al., 1996), is to study cetacean watching and cetaceans without adding to the disturbance of cetaceans.

One of the best ways to measure and record spatial parameters, without influencing cetacean behavior, is to work from land, using theodolites, high-power binoculars, and digital video recorders (IFAW et al., 1996). Theodolite studies from land have been a feature of whale research since at least the late 1970s (e.g., the work by Darling and others on humpback whales in Hawaii). More recently, theodolites have been used in whale-watching studies in Johnstone Strait, British Columbia (Kruse, 1991); Haro Strait, Washington, USA (Phillips \& Baird, 1993; Baird, Otis, \& Osborne, 1998); and in the Tysfjord area of Norway (DeNardo, 1998). A number of Caribbean locations offer ideal situations to conduct such studies, the most promising of which are listed in Table 1.

Both the 1995 Scientific Aspects of Managing Whale-Watching Workshop and the 1996 Sperm Whale-Watching Workshop recommended the use of pristine areas closed to whale-watching to gather baseline data on the "normal" behavior of whales, and to serve as control situations for comparisons with places where whale-watching might be changing the distribution, behavior, or other characteristics of whales (IFAW et al., 1996; IFAW, 1997). Of course, this possibility depends on the extent to which the particular 
Table 1

Potential land-based cetacean monitoring and study sites in the Greater Caribbean

\begin{tabular}{lcc}
\hline $\begin{array}{l}\text { Country/ } \\
\text { dependency }\end{array}$ & Land-based monitoring \\
$\&$ study sites & Species
\end{tabular}

\begin{tabular}{|c|c|c|}
\hline Antigua \& & Shirley Heights & Megaptera (Jan.-Mar.) \\
\hline \multirow[t]{2}{*}{ Barbuda } & Indian Creek & Tursiops \\
\hline & N. of Spanish Point (Barbuda) & Stenella frontalis; Tursiops \\
\hline \multirow[t]{2}{*}{ Bahamas } & $\begin{array}{l}\text { Hole-in-the-Wall Lighthouse, } \\
\text { Abacos* }\end{array}$ & $\begin{array}{l}\text { Stenella frontalis; Tursiops; } \\
\text { Physeter; Megaptera; } \\
\text { Pseudorca: Globicephala; } \\
\text { Mesoplodon spp. }\end{array}$ \\
\hline & Lighthouse on Elbow Cay, Abacos* & Tursiops \\
\hline \multirow[t]{3}{*}{ Dominica } & Scotts Head & Physeter; Delphinidae spp. \\
\hline & Pointe Michel & Physeter; Delphinidae spp. \\
\hline & West coast (high vantage points) & Physeter; Delphinidae spp. \\
\hline \multirow{6}{*}{$\begin{array}{l}\text { Dominican } \\
\text { Republic }\end{array}$} & Cabo Francés Viejo** & Megaptera (Jan.-Mar.) \\
\hline & Cueva de Agua** & Megaptera (Jan.-Mar.) \\
\hline & Punta Balandra Light* & Megaptera (Jan.-Mar.) \\
\hline & Cabo Samaná* & Megaptera (Jan.-Mar.) \\
\hline & Cabo Engano & Megaptera (Jan.-Mar.) \\
\hline & Parque Nacional del Este (SE DR) & Delphinidae spp. \\
\hline $\begin{array}{l}\text { Guadeloupe } \\
\text { (France) }\end{array}$ & West coast (high vantage points) & Physeter; Delphinidae spp. \\
\hline $\begin{array}{r}\text { Martinique } \\
\text { (France) }\end{array}$ & West coast (high vantage points) & Physeter; Delphinidae spp. \\
\hline \multirow{2}{*}{$\begin{array}{l}\text { Puerto Rico } \\
\text { (USA) }\end{array}$} & Aguadilla & Megaptera (Jan.-Mar.) \\
\hline & $\begin{array}{l}\text { Punta Higuera light house } \\
\text { (near Rincón)* }\end{array}$ & Megaptera (Jan.-Mar.) \\
\hline \multirow[t]{2}{*}{ St. Lucia } & $\begin{array}{l}\text { Anse Chastanet \& vantage } \\
\text { points over Soufrière Bay }\end{array}$ & Physeter; Delphinidae spp. \\
\hline & $\begin{array}{l}\text { Northwest coast (high vantage } \\
\text { points) }\end{array}$ & Physeter; Delphinidae spp. \\
\hline $\begin{array}{l}\text { Turks \& } \\
\text { Caicos (UK) }\end{array}$ & Salt Cay** & Megaptera (Jan.-Apr.) \\
\hline
\end{tabular}

* Sites already used for scientific research and monitoring of cetaceans.

**Prime land-based sites used already for whale watch tours. 
cetacean species has site fidelity. This type of closure for research should, of course, carefully consider the current and potential economic benefits to nearby communities and businesses. However, if the closure were restricted to only a part of certain areas, it might not damage and could even enhance the value of the overall area to communities. In the Dominican Republic, for example, portions of the humpback whale habitat at protected Silver Bank or currently unprotected Navidad Bank, both of which are sparsely visited by whale watch boats, could be used to compare with data from Samaná Bay where the vast majority of the humpback whale-watching occurs in the Caribbean. Similarly, the broad distribution of sperm whale groups throughout the region, with regular sightings from Cuba and Jamaica to at least St. Lucia in the eastern Caribbean, provides a number of possible areas in the lee of islands which could be designated for control studies.

\section{Conclusion}

In the Caribbean, tourism is the leading industry in terms of people employed, revenues, and source of foreign exchange. Even though the rapidly growing whale-watching industry is only a small direct component of tourism in the Caribbean, the views, attitudes, backgrounds, satisfactions, and disappointments of all tourists (including whalewatching tourists), related to any aspect of the tourism industry, are crucial pieces of information (Hvenegaard, 1997). Since the commercial whale-watching industry capitalizes on tourists' interest in nature-based forms of recreation, the tourism industry should be especially concerned about tourists' attitudes to the environment and to conservation, which is reflected in attitudes to whaling and whale-watching. Evidence elsewhere suggests that continued whaling in the Caribbean has the potential to undermine the whalewatching industry, as well as to have a negative impact on overall tourism.

Experiences elsewhere can provide possible indicators, but further research in the Caribbean is needed to assess the compatibility of whale-watching and whaling. In particular, it would be valuable to determine the views and attitudes of local residents, whale watchers, and other tourists to the Caribbean, about ecotourism, whale-watching, the environment in general, and their concerns, if any, about whaling in general and cetacean hunting in the Caribbean. How much would the tourism economy of a Caribbean nation suffer, in terms of negative publicity and lower tourism revenue, if it encourages or permits the killing of cetaceans? Moreover, the negative impacts of whalewatching should also be considered in terms of disturbance to or harassment of whales and subsequent satisfactions and attitudes of whale watchers. Building on these results, the potential incompatibility between whale-watching and whaling can be clarified by measuring the social and economic benefits and costs in a comprehensive economic welfare and economic impact assessment (IFAW, 1999).

Cetacean hunting and whale-watching currently coexist in some circumstances but insufficient time has elapsed to be able to judge all of the long-term impacts on the whale-watching and tourism industries. Any proposal to ban cetacean hunting, in order to promote the whale-watching or tourism industries, would certainly need to consider all of the related values of using whales for all purposes. If a country seeks to continue with a cetacean hunting industry, attention should be given to improving public understanding of the industry's history and associated values (World Council of Whalers, 1999). The success of management efforts will depend on local conservation concerns and the level of spatial, temporal, and species overlap between cetacean hunting and whale-watching.

Given that opposition to whaling is strong and growing, particularly in source countries for large numbers of foreign tourists, host countries must be cautious about the 
negative attitudes of incoming tourists. One of a country's most valuable tourism assets is its image. Millions of dollars are spent to devise, shape, and market the popular image of a tourism destination. In the increasingly competitive world tourism market, a country must carefully consider the implications of any activities that might negatively affect that image.

\section{Notes}

1. Direct expenditure is defined as the amount tourists spent on tickets to go whale-watching. Total expenditures refer to the amount tourists spent on tickets, transport, food, hotels, souvenirs, and other expenses associated with the trip and the decision to go whale-watching (Hoyt, 2001).

2. Hoyt (2001) reports an additional minimum of 50,000 whale watchers in the Caribbean for 1998, all from Puerto Rico, due to more recent data. This would change the total figure from 39,000 to 89,000 for all the Caribbean. However, the additional numbers are land-based watchers who spent only an estimated $\$ 10$ each or $\$ 500,000$ total. Thus, the total expenditures are only slightly more than the original estimate of $\$ 10$ million. These land-based watchers may have gone uncounted in estimates from previous years. The rates of increase are based on the original 39,000 estimate.

\section{References}

Adams, C. E., J. A. Leifester, and J. S. C. Herron. 1997. Understanding wildlife constituents: Birders and waterfowl hunters. Wildlife Society Bulletin 25(3):653-660.

Au, D., and W. Perryman. 1982. Movement and speed of dolphin schools responding to an approaching ship. U.S. Fisheries Bulletin 80:371-379.

Baird, R. W., R. Otis, and R. W. Osborne. 1998. Killer whales and boats in the Haro Strait area: Biology, politics, esthetics and human attitudes. In Abstracts of the Whale-Watching Research Workshop, World Marine Mammal Science Conference, Monaco, http://office.geog.uvic.ca/dept/whale/abstract.html.

Bjorgvinsson, A. 1997. Whale watching in Iceland 1997. Bath, UK: Whale and Dolphin Conservation Society.

Caldwell, D. K., and M. C. Caldwell. 1971. Porpoise fisheries in the southern Caribbean-Recent utilization and future potential. Proceedings of the Annual Session of the Gulf and Caribbean Fisheries Institute, 195-206.

Constantine, R. 1999. Effects of tourism on marine mammals in New Zealand. Wellington, New Zealand: Department of Conservation.

Darling, J. 1991. Humpback whales win Japanese. Whalewatcher 25(2):12-15.

Day, S. V. 1987. Estimating the non-consumptive use value of whale watching: An application of the travel cost and contingent valuation techniques. M.Sc. Thesis, University of Rhode Island, Providence, RI.

DeNardo, C. 1998. Investigating the role of spatial structure in killer whale (Orcinus orca) behavior. M.Sc. Thesis, University of Aberdeen, Aberdeen, Scotland.

Dowling, R. 1991. Tourism and the natural environment: Shark Bay, Western Australia. Tourism Recreation Research 16(2):44-48.

Duffus, D. A. 1988. Non-consumptive use and management of cetaceans in British Columbia coastal waters. Ph.D. Dissertation, University of Victoria, Victoria, BC, Canada.

Ellis, R. 1991. Men and whales. New York: Knopf.

Fisher, S. 2001. Unpublished data on recent voting records of Caribbean countries. Bath, UK: Whale and Dolphin Conservation Society.

Freeman, M. M. R., and S. R. Kellert. 1992. Public attitudes to whales: Results of a six-country survey. Edmonton, AB: Canadian Circumpolar Institute, University of Alberta.

Goßling, S. 1997. The economic, ecological and social role of whale tourism in Norway. Norden 12:117125. Translated into English by the author.

Goddard, J. 2000. Whale watchers and whale consumers come together in Norway. Brentwood Bay, BC, World Council of Whalers, http://www.worldcouncilofwhalers.com/oct202000.htm.

Gordon, J., A. Moscrop, C. Carlson, S. Ingram, R. Leaper, J. Matthews, and K. Young. 1998. Distribution, movements and residency of sperm whales off the Commonwealth of Dominica, Eastern Caribbean: Implications for the development and regulation of the local whalewatching industry. Report of the International Whaling Commission 48:551-557. 
Hamazaki, T., and D. Tanno. 2001. Approval of whaling and whaling-related beliefs: Public opinion in whaling and nonwhaling countries. Human Dimensions of Wildlife 6:131-144.

Hammitt, W. E., J. N. Dulin, and G. R. Wells. 1993. Determinants of quality wildlife viewing in Great Smoky Mountains National Park. Wildlife Society Bulletin 21(1):21-30.

Hoagland, P., and A. E. Meeks. 1997. The demand for whalewatching at Stellwagen Bank National Marine Sanctuary. Woods Hole, MA: Woods Hole Oceanographic Institution.

Hoyt, E. 1993. Kujira watching. Bath, UK: Whale and Dolphin Conservation Society.

Hoyt, E. 1994a. Whale watching and the community: The way forward. Bath, UK: Whale and Dolphin Conservation Society.

Hoyt, E. 1994b. The potential of whale watching in Latin America and the Caribbean. Bath, UK: Whale and Dolphin Conservation Society.

Hoyt, E. 1995. The worldwide value and extent of whale watching: 1995. Bath, UK: Whale and Dolphin Conservation Society.

Hoyt, E. 1996a. An ecological-cultural tourism assessment plan: Strategies for the communities of the Hata-Wide area. Lecture to the First Ecotourism Assessment \& Strategic Management Planning Meeting for Ogata and the surrounding communities of the Hata-Wide region, Whalewatching Centre, Irino Port, Ogata-cho, Kochi-ken, Japan, March 5.

Hoyt, E. 1996b. Whale watching and community development around the world. In Proceedings of the International Whale Watching Festa '96, 15-32, Zamami, Okinawa, Japan.

Hoyt, E. 1999. The potential of whale watching in the Caribbean: 1999+. Bath, UK: Whale and Dolphin Conservation Society.

Hoyt, E. 2001. Whale watching: Worldwide tourism numbers, expenditures, and expanding socioeconomic benefits. Yarmouth Port, MA: International Fund for Animal Welfare.

Hoyt, E. 2002. Whale watching. In Encyclopedia of marine mammals, eds. W. R. Perrin, B. Würsig, and J. G. M. Thewissen, 1305-1310. San Diego, CA: Academic Press.

Hvenegaard, G. T. 1997. The social and economic aspects of ecotourism: A review relevant to whale watching. Paper presented at the Workshop on the Socioeconomic Aspects of Whale Watching, Kaikoura, New Zealand, December 8.

Hvenegaard, G. T., J. R. Butler, and D. K. Krystofiak. 1989. The economic values of bird watching at Point Pelee National Park, Canada. Wildlife Society Bulletin 17:526-531.

IFAW. 1997. Report of the Workshop on the Special Aspects of Watching Sperm Whales. Crowborough, UK: International Fund for Animal Welfare.

IFAW. 1999. Report of the Workshop on the Socioeconomic Aspects of Whale Watching. Yarmouth Port, MA, International Fund for Animal Welfare.

IFAW, Tethys Research Institute, and Europe Conservation. 1996. Report of the Workshop on the Scientific Aspects of Managing Whale Watching. Crowborough, UK: International Fund for Animal Welfare.

International Wildlife Coalition. 2000. The slaughter continues in Bequia! http://iwc.org/caribbeanwhaling/ caribbeanwhaling.htm, 2 pp.

Jefferson, T. A., S. Leatherwood, and M. A. Webber. 1993. Marine mammals of the world, FAO species identification guide. Rome: FAO \& UNEP.

Jones, M. L., and S. L. Swartz. 2002. Gray Whale, Eschrichtius robustus. In Encyclopedia of marine mammals, eds. W. R. Perrin, B. Wursig, and J. G. M. Thewissen, 524-536. San Diego, CA: Academic Press.

Kellert, S. R. 1978. Characteristics and attitudes of hunters and anti-hunters. Transactions of the North American and natural resources conference 43:412-423.

Kellert, S. R. 1999. American perceptions of marine mammals and their management. Washington, DC: The Humane Society of the United States.

Kraus, S. D. 1989. Whales for profit. Whalewatcher 23(2):18-19.

Kruse, S. 1991. The interactions between killer whales and boats in Johnstone Strait, B.C. In Dolphin societies, eds. K. Pryor and K. S. Norris, 149-159. Berkeley, CA: University of California Press.

Lavigne, D. M., V. B. Scheffer, and S. R. Kellert. 1999. The evolution of North American attitudes toward marine mammals. In Conservation and management of marine mammals, eds. J. R. Twiss, Jr., and R. R. Reeves, 10-47. Washington, DC: Smithsonian Institution Press.

Lewis, K. T. 1988. Survey of attitudes and knowledge of New England whalewatchers. New Haven, CT: Yale School of Forestry and Environmental Studies.

Loomis, J., S. Yorizane, and D. Larson. 2000. Testing significance of multi-destination and multi-purpose trip effects in a travel cost method demand model for whale-watching trips. Agricultural and Resource Economics Review 29:183-191.

Lynge, F. 1992. Arctic wars, animal rights, endangered peoples. Hanover, NH: University Press of New England. Translated by Marianne Stenbaek.

McCloskey, M. 1983. Recreational whale-watching. Paper presented at Global Conference on the NonConsumptive Utilization of Cetacean Resources. Boston, MA. 
McCool, S. F. 1996. Wildlife viewing, natural area protection, and community sustainability and resiliency. Natural Areas Journal 16(2):147-151.

More, T. A. 1979. The demand for nonconsumptive wildlife uses: A review of the literature. Broomall, PA: USDA Forest Service, Northeastern Forest Experiment Station, General Technical Report NE-52.

Moyle, B. J., and M. Evans. 2001. A bioeconomic and socio-economic analysis of whale-watching, with attention given to associated direct and indirect costs. Unpublished report to the Scientific Committee of the International Whaling Commission, London.

Muloin, S. 1998. Wildlife tourism: The psychological benefits of whale watching. Pacific Tourism Review 2(3/4):199-213.

New Zealand Tourism Board. 1996. New Zealand International Visitors Survey. Wellington: New Zealand Tourism Board.

Orams, M. B. 1999. The economic benefits of whale watching in Vava'u, the Kingdom of Tonga. North Shore, New Zealand: Centre for Tourism Research, Massey University at Albany.

Orams, M. B. 2000. Tourists getting close to whales, is it what whale-watching is all about? Tourism Management 21:561-569.

Orams, M. B. 2001. From whale hunting to whale watching in Tonga: A sustainable future? Journal of Sustainable Tourism 9:128-146.

Papastavrou, V. 1996. Sustainable use of whales: Whaling or whale watching? In The exploitation of mammal populations, eds. V. J. Taylor and N. Dunstone, 102-113. London, UK: Chapman and Hall.

Phillips, N. E., and R. W. Baird. 1993. Are killer whales harassed by boats? Victoria Naturalist 50(3):1011.

Quimby, S. 2000. An introduction to whaling issues. Caribbean Currents 8(2):1-4.

Reeves, R. 1988. Exploitation of cetaceans in St. Lucia, Lesser Antilles, January 1987. Report of the International Whaling Commission 38:445-447.

Reid, E. 1993. An environmental profile: The whale watchers of Encounter Bay, South Australia. M.E.S. Thesis, University of Adelaide, Adelaide, Australia.

Reid, E. 1996. Whale watchers of the Head of the Bight: A 1995 visitor profile and implications for management. Adelaide, Australia: University of Adelaide, Mawson Graduate Centre for Environmental Studies, Occasional Paper No. 11.

Ris, M. 1993. Conflicting cultural values: Whale tourism in northern Norway. Arctic 46(2):156-163.

Romero, A., and K. Hayford. 2000. Past and present utilisation of marine mammals in Grenada, West Indies. Journal of Cetacean Research and Management 2:223-226.

Shaw, W. W., and D. A. King. 1980. Wildlife management and nonhunting wildlife enthusiasts. Transactions of the North American Wildlife and Natural Resources Conference 45:219-225.

Shaw, W. W., D. Witter, D. A. King, and M. Richards. 1978. Non-hunting wildlife enthusiasts and wildlife management. Proceedings of the Western Association of Fish and Wildlife Agencies 58:255-263.

Smith, T. D., J. Allen, P. J. Clapham, P. S. Hammond, S. Katona, F. Larsen, J. Lien, D. Mattila, P. J. Palsbøll, J. Sigurjónsson, P. T. Stevick, and N. Øien. 1999. An ocean-basin-wide mark-recapture study of the North Atlantic Humpback Whale (Megaptera novaeangliae). Marine Mammal Science 15:1-32.

Taylor, B. L. 2002. Conservation biology. In Encyclopedia of marine mammals, eds. W. R. Perrin, B. Wursig, and J. G. M. Thewissen, 273-276. San Diego, CA: Academic Press.

Thresher, P. 1981. The economics of a lion. Unasylva 33(134):34-35.

Tilt, W. C. 1987. From whaling to whalewatching. Transactions of the North American Wildlife and Natural Resources Conference 52:567-585.

Utech, D. 1999. Valuing Hawaii's humpback whales: The economic impact of humpbacks on Hawaii's ocean tour boat industry. Honolulu, HI: Hawaiian Islands Humpback Whale National Marine Sanctuary.

Vidal, O., and K. Van Waerebeek. 1994. Cetaceans and gillnet fisheries in Mexico, Central America and the Wider Caribbean: A preliminary review. Report of the International Whaling Commission, Special Issue 15:221-233.

Ward, A., and A. Moscrop. 1999. Marine mammals of the wider Caribbean region: A review of their conservation status. Paper presented at the Fourth Meeting of the Interim Scientific and Technical Advisory Committee to the Protocol Concerning Specially Protected Areas and Wildlife in the Wider Caribbean Region, Havana, Cuba. 3-6 August.

Watkins, W. A. 1986. Whale reactions to human activities in Cape Cod waters. Marine Mammal Science 2(4):251-262.

Weber, W. 1987. Ruhengeri and its resources: An environmental profile of the Ruhengeri Prefecture, Rwanda. Kigali, Rwanda: Ruhengeri Resource Analysis and Management Project.

Weller, D. W., B. Würsig, A. L. Bradford, A. M. Burdin, S. A. Blokhin, H. Minakuchi, and R. L. Brownell, Jr. 1999. Gray whales (Eschrichtius robustus) off Sakhalin Island, Russia: Seasonal and annual patterns of occurrence. Marine Mammal Science 15:1208-1227. 
Western, D., and W. Henry. 1979. Economics and conservation in third world national parks. BioScience 29(7):414-418.

WDCS. 1998. Subsidies in the Norwegian whaling industry. Bath, UK: Whale and Dolphin Conservation Society.

WDCS. 1999. Humpback whaling in St. Vincent and the Grenadines. Bath, UK: Whale and Dolphin Conservation Society.

World Council of Whalers. 1999. Whaling and the Caribbean People. Brentwood Bay, BC: World Council of Whalers, http://www.worldcouncilofwhalers.com/WCWNews/WCWnewsl5.html.

World Council of Whalers. 2000. Whaling in the Caribbean. Brentwood Bay, BC: World Council of Whalers, http://www.worldcouncilofwhalers.comworld/caribbean.html. 
Copyright of Coastal Management is the property of Taylor \& Francis Ltd and its content may not be copied or emailed to multiple sites or posted to a listserv without the copyright holder's express written permission. However, users may print, download, or email articles for individual use. 